\title{
Proizvodnost traktora Ecotrac 120V pri privlačenju drva u brdskom području središnje Hrvatske
}

\author{
Željko Zečić, Zlatko Benković, Ivica Papa, Jurij Marenče, Dinko Vusić
}

\begin{abstract}
Nacrtak - Abstract
U radu su prikazani rezultati istraživanja proizvodnosti rada skidera Ecotrac 120 V na privlačenju drva poludeblovnom metodom iz proredne i dovršne sječine. Terensko je istraživanje provedeno studijem rada i vremena. Razlike u obujmu tovara, brzini vožnji, izvlačenju užeta i privitlavanju te razlike u utrošku vremena pojedinih radnih zahvata na sječini i rada na pomoćnom stovarištu istražene su t-testom. Za radne zahvate za koje je utvrđena značajna razlika između promatranih sječina u daljnjim su izračunima primijenjene individulne prosječne vrijednosti za pojedinu sječinu, dok su kod ostalih radnih zahvata izračunate nove, zajedničke prosječne vrijednosti. Utrošci vremena vožnji izračunati su na temelju prosječne brzine i udaljenosti privlačenja. Utvrđena je značajna razlika između obujma tovara iz proredne i dovršne sječine. Razlike su u utrošku vremena najočitije u skupini radnih zahvata na sječini, a nastaju kao posljedica različite udaljenost i izvlačenja užeta i privitlavanja tovara. Projektirani dnevni učinak u dovršnom je sijeku prosječno $21 \%$ veći nego u prorednoj sječi uz prosječno $26 \%$ niže jedinične troškove. Detaljnom analizom utrošaka vremena pojedinih radnih zahvata utvrđeno je da na razliku u proizvodnosti i troškovima bitan utjecaj imaju sječna gustoća sastojine i prosječan obujam posječenoga stabla. Različita sječna gustoća utječe na različit utrošak vremena rada na sječini i posljedično na ostvarivi dnevni učinak. Na proizvodnost rada skidera uz sječnu gustoću još veći utjecaj ima prosječni obujam posječenoga stabla jer omogućuje formiranje tovara zadovoljavajućega obujma na kratkoj udaljenosti privitlavanja vezivanjem manjega broja komada, često uz upotrebu samo jednoga bubnja vitla. Stoga se može zaključiti da mogućnost postizanja najvećih učinaka u zadanim sastojinskim i eksploatacijskim uvjetima leži u optimalnom odnosu između veličine tovara i vremena utrošenoga pri radu na sječini koje je nužno za njegovo formiranje.
\end{abstract}

Ključne riječi: proizvodnost, troškovi, sječna gustoća, prosječni obujam posječenoga stabla, proreda, dovršni sijek

\section{Uvod - Introduction}

Mehanizirano privlačenje drva u šumarstvu Republike Hrvatske počinje šezdesetih godina dvadesetoga stoljeća (Zečić 2006). Tada se poljoprivredni traktori opremaju vitlima i zaštitnim kabinama za rad u šumi. Prvi specijalizirani šumski zglobni traktori za privlačenje drva po tlu (skideri) počinju se primjenjivati 1968. godine nakon čega kreće intenzivno mehaniziranje svih faza pridobivanja drva. Usporedno s uvođenjem novih strojeva započela je izobrazba radnika i intenziviran je znanstvenoistraživački rad. Ponuđena su rješenja domaćih stručnja- ka u razvoju radnih sredstava i tehnologije, izrađene su tehničke norme i započeta su istraživanja ergonomskih značajki strojeva.

U Hrvatskoj je u okviru državnih šuma 1995. godine drvo privlačilo 188 adaptiranih poljoprivrednih traktora, 270 skidera, 23 forvardera te 43 traktora s poluprikolicom (Zečić 1998). Horvat i dr. (2007) navode da u vlasništvu poduzeća »Hrvatske šume« d.o.o. radi oko 300 skidera i procjenjuju da je još oko 100 skidera u vlasništvu privatnih poduzetnika. Od navedenoga broja preko 100 je prorednih, mase ispod $4 \mathrm{t}$, koji su razvijeni i proizvedeni $\mathrm{u}$ Hrvatskoj. Preostalih oko 300 skidera, mase preko $7 \mathrm{t}$, bili su 
strane proizvodnje. Rezultati istraživanja tih uvoznih skidera upućivali su na određene nedostatke. Skideri tipa LKT imali su zadovoljavajuće morfološke značajke, ali i zastarjela tehnička rješenja koja su u prvi plan isticala ekološku neprilagođenost, a skideri tipa Timberjack 240C, iako visoko proizvodni, za naše su šumske uvjete bili predimenzionirani i s nepotpuno usklađenim ergonomskim rješenjima (Zečić 2006). Krč i Košir (2008) istražuju najpovoljnije načine privlačenja drva $u$ odnosu na primarnu i sekundarnu otvorenost šumske površine izradom digitalnih modela terena, a Marenče i Košir (2008) istražuju novi traktor Woody 110 pri privlačenju drva uz nagib.

Zbog potreba hrvatskoga šumarstva za skiderima mase preko $7 \mathrm{t}$ pokreće se proizvodnja domaćega skidera u tvornici Hittner d.o.o. u Bjelovaru. Nakon četiri desetljeća zajedničkoga rada šumarske prakse i znanosti danas u šumarstvu u Hrvatskoj, uz šumske zglobne traktore strane proizvodnje, postoje i tri tipa skidera domaće proizvodnje: Ecotrac $55 \mathrm{~V}$ za privlačenje drva većinom iz prorednih sječina te Ecotrac $120 \mathrm{~V}$ i $140 \mathrm{~V}$ za privlačenje drva uglavnom iz oplodnih i prebornih sječina. U trgovačkom društvu »Hrvatske šume« d.o.o. Zagreb do 2011. godine drvo iz šuma privlače 122 skidera mase manje od 5 t i 176 skidera mase veće od 5 t, od kojih su 94 tipa Ecotrac 120V. Navedeni tip traktora postupno je posljednjih godina zamjenjivao različite modele LKT skidera koji su tridesetak godina bili najrasprostranjeniji, dok su svi skideri tipa Timberjack 240C, njih 45, zahvaljujući i relativno kratkomu vremenu korištenja, a u prvom redu kakvoći izrade, kontinuirano u upotrebi već više od desetak godina.

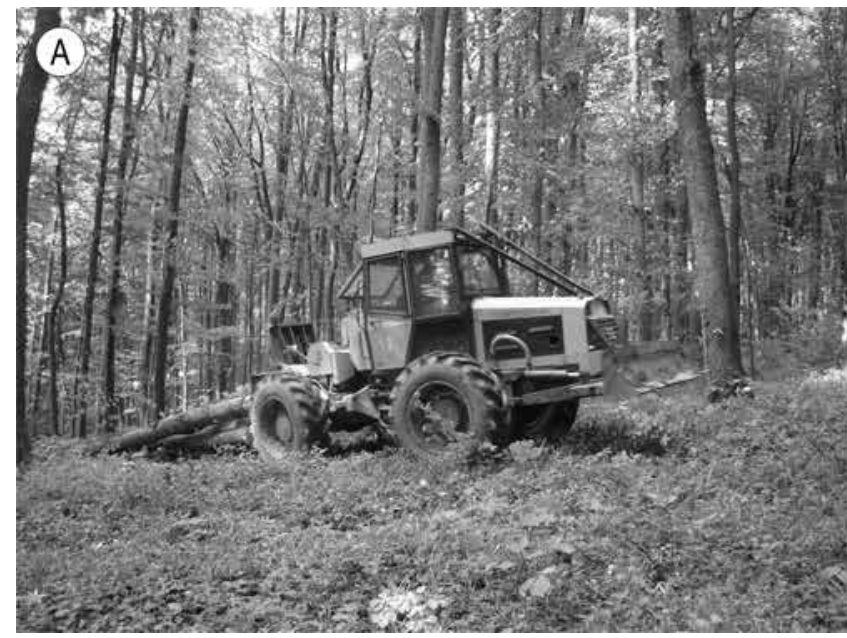

Navedeni je broj skidera tipa Ecotrac 120V ravnomjerno raspoređen na privlačenju drva iz oplodnih, a često i prorednih sječina središnje Hrvatske te na privlačenju drva iz prebornih sječina u Lici i Gorskom kotaru, gdje se nalazi više traktora tipa Ecotrac 140V.

Cilj je ovoga rada utvrditi postoje li razlike u proizvodnosti skidera Ecotrac $120 \mathrm{~V}$ pri privlačenju drva iz proredne i dovršne sječine te $u$ slučaju postojanja razlike detaljnom analizom utrošaka vremena pojedinih radnih sastavnica utvrditi razloge koji utječu na različitu proizvodnost.

\section{Materijal i metode Material and methods}

Terenska su istraživanja provedena na dvama radilištima. Radilište A (odsjek 2 A) nalazi se na području Uprave šuma podružnice Bjelovar, Šumarije Garešnica, u gospodarskoj jedinici »Dišnica-Zobikovac-Petkovača«, a radilište B (odsjek $46 \mathrm{~A}$ ) nalazi se na području Uprave šuma podružnice Koprivnica, Šumarije Đurđevac, u gospodarskoj jedinici »Đurđevačka Bilogora«. Na radilištu $\mathrm{A}$, u mješovitoj sastojini bukve $(48,74 \%)$, hrasta kitnjaka $(4,47 \%)$, graba $(21,06 \%)$ i lipe $(15,65 \%)$, u dobi od 57 godina, obavljena je proredna sječa. Posječeno je $34,07 \mathrm{~m}^{3} / \mathrm{ha}$, a prosječni obujam posječenoga stabla iznosi $0,63 \mathrm{~m}^{3}$. Na radilištu B, u bukovoj $(92,03 \%)$ sastojini, u dobi od 111 godina, obavljen je dovršni sijek. Posječeno je $89,50 \mathrm{~m}^{3} /$ ha, a prosječni obujam posječenoga stabla iznosi $3,51 \mathrm{~m}^{3}$. U oba istraživana slučaja primijenjena je poludeblovna metoda privlačenja drva skiderom Ecotrac 120V. Na radilištu A drvo je privlačeno

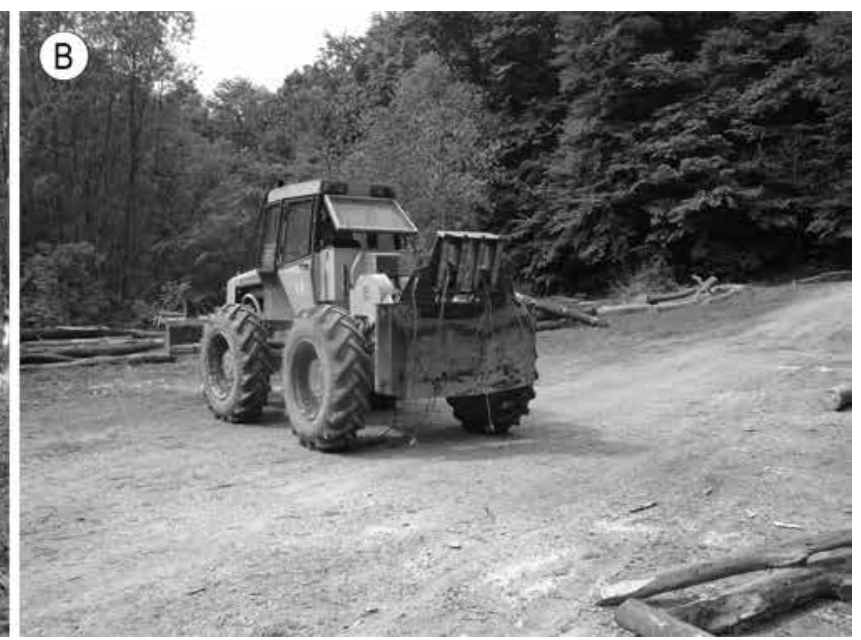

Slika 1. Ecotrac $120 \mathrm{~V}$ na vlaci $(A)$ i na pomoćnom stovarištu $(B)$ Fig. 1 Ecotrac 120V on skidding trail $(A)$ and on landing site $(B)$ 
na srednjoj udaljenosti od $550 \mathrm{~m}$ i uz prosječni nagib vlaka $+10 \%$, dok je na radilištu B srednja udaljenost privlačenja iznosila $300 \mathrm{~m}$, a prosječni nagib vlaka $-8 \%$.

Istraživani je skider Ecotrac 120V (slika 1) četverokotačno vozilo (pogona $4 \times 4$ ) opremljeno dvobubanjskim šumskim vitlom Hittner $2 \times 80$, nazivne vučne sile od 80 kN (Šušnjar i dr. 2010). Masa je skidera $7257 \mathrm{~kg}$, a pogonjen je šestocilindričnim dizelskim motorom DEUTZ, nazivne snage $84 \mathrm{~kW}$ pri $2300 \mathrm{~min}^{-1}$ te najvećega zakretnoga momenta od 400 Nm pri 1500 min $^{-1}$ (Šušnjar i dr. 2010).

Terenska su istraživanja privlačenja drva obavljena studijem rada i vremena (Zečić i dr. 2004b, Sabo i Poršinsky 2005). Ukupno je snimljeno 66 turnusa privlačenja na radilištu A i 52 turnusa privlačenja na radilištu B. Turnus je privlačenja raščlanjen na radne zahvate prethodno definiranim fiksažnim točkama (Zečić i dr. 2011b). Utrošci vremena pojedinih radnih zahvata te vremena prekida mjereni su povratnom metodom kronometrije (Zečić i dr. 2004b). Evidentirani su podaci o privučenom tovaru, o udaljenosti privlačenja te o udaljenosti izvlačenja užeta i privitlavanja pojedinoga bubnja vitla. Analizom snimljenih prekida utvrđeno je dodatno vrijeme (Zečić 1999).

Prikupljeni podaci o utrošcima vremena pojedinih radnih sastavnica statistički su obrađeni. T-testom su analizirane razlike između brzine vožnji skidera na radilištu A i radilištu B (Zečić i dr. 2011b). $\mathrm{U}$ daljnjem je izračunu, sukladno rezultatima $t$-testa, uzeta pojedinačna ili zajednička prosječna brzina vožnji. Na sličan je način izračunata proizvodnost skidera kao rezultat izjednačenja utrošaka vremena vožnji o udaljenosti privlačenja pravcem iz ishodišta, što su istraživali Sabo i Poršinsky (2005). Brzina izvlačenja užeta te brzina privitlavanja obrađene su na isti način. Vrijeme radnih zahvata rada na sječini te rada na pomoćnom stovarištu također je testirano $t$-testom i sukladno rezultatima za izračun ukupnoga vremena turnusa korištene su prosječne vrijednosti ostvarene na pojedinom radilištu ili zajedničke prosječne vrijednosti (Zečić i dr. 2011b). Istim su testom istražene i razlike $u$ prosječnom obujmu tovarâ privučenih na oba radilišta (Sabo i Poršinsky 2005).

Efektivno vrijeme za projektirani turnus privlačenja na radilištima A i B izračunato je za raspon privlačenja po vlaci od $100 \mathrm{~m}$ do $1000 \mathrm{~m}$. Utrošak vremena vožnji opterećenoga i neopterećenoga skidera na vlaci izračunat je na temelju pripadajućih brzina vožnji i udaljenosti u navedenom rasponu. Izračunatom utrošku vremena vožnji opterećenoga skidera na vlaci pribrojeno je prosječno utrošeno vrijeme za otpuštanje i privitlavanje tovara u vožnji. Na sličan su način izračunati i utrošci vremena vožnji skidera na pomoćnom stovarištu, ali za zajedničku prosječnu udaljenost privlačenja. Utrošak je vremena za rad na sječini rezultat odnosa brzine izvlačenja užeta i privitlavanja te pripadajućih prosječnih udaljenosti za pojedinačni bubanj vitla kojima su pribrojeni prosječni pripadajući utrošci ostalih radnih zahvata. Utrošak vremena za rad na pomoćnom stovarištu pojedinoga radilišta rezultat je zbroja pripadajućih prosječnih utrošaka vremena za pojedine radne zahvate.

Efektivno vrijeme uvećano utvrđenim dodatnim vremenom razultiralo je ukupnim vremenom turnusa čijim su dijeljenjem s ostvarenim srednjim obujmom tovara pojedinoga radilišta izračunate pripadajuće norme vremena.

Dijeljenjem propisanoga trajanja radnoga dana (480 min) s ukupnim vremenom turnusa izračunati su brojevi turnusa koje je moguće ostvariti s obzirom na raspon srednjih udaljenosti privlačenja.

Dnevni učinak iskazan za osmosatno radno vrijeme rezultat je dijeljenja propisanoga trajanja radnoga dana (480 $\mathrm{min}$ ) normom vremena, odnosno množenja ostvarivoga broja turnusa sa srednjim obujmom tovara.

Na osnovi kalkulativne cijene osmosatnoga rada skidera Ecotrac 120V i vozača u iznosu od 1889 kn/ dan (Anon. 2008) izračunati su jedinični troškovi za pojedino radilište u ovisnosti o srednjoj udaljenosti privlačenja.

\section{Rezultati i rasprava Results and discussion}

Tijekom istraživanja ukupno je snimljeno 2936,22 minuta na radilištu A i 2126,54 minuta na radilištu B. Za to je vrijeme skider na radilištu A privukao $198,25 \mathrm{~m}^{3}$ neto obujma i ostvario dnevni učinak od $28,32 \mathrm{~m}^{3} /$ dan, a skider na radilištu $\mathrm{B} 193,27 \mathrm{~m}^{3}$ neto obujma i ostvario dnevni učinak od $38,65 \mathrm{~m}^{3} /$ dan. Struktura ukupno utrošenoga vremena prikazana je u tablici 1.

Prosječni obujam tovara iznosio je $3,05 \mathrm{~m}^{3}(1,21$ $\left.\mathrm{m}^{3}-6,17 \mathrm{~m}^{3}\right)$ na radilištu A i 3,72 $\mathrm{m}^{3}\left(1,61 \mathrm{~m}^{3}-7,19\right.$ $\left.\mathrm{m}^{3}\right)$ na radilištu $\mathrm{B}$. Rezultati $t$-testa $(t=-3,571562 ; p$ $=0,000519$ ) pokazuju postojanje značajne razlike $\mathrm{u}$ obujmu tovarâ privučenih na radilištu A i na radilištu B. Stoga su pri izračunu norme vremena uzete individualne vrijednosti prosječnoga obujma tovara za pojedino radilište. 
Tablica 1. Struktura ukupno utrošenoga vremena i prosječno ostvareni dnevni učinak skidera Ecotrac $120 \mathrm{~V}$ Table 1 Structure of total time consumption and average daily output of Ecotrac 120V skidder

\begin{tabular}{|c|c|c|c|c|c|c|}
\hline \multirow{5}{*}{$\begin{array}{l}\text { Radne sastavnice } \\
\text { Work cycle element }\end{array}$} & \multicolumn{3}{|c|}{ Radilište A - Work site $A$} & \multicolumn{3}{|c|}{ Radilište $B$ - Work site $B$} \\
\hline & \multicolumn{6}{|c|}{ Utrošak vremena - Time consumption } \\
\hline & \multirow{2}{*}{$\begin{array}{l}\text { Ukupno } \\
\text { vrijeme } \\
\text { Total time }\end{array}$} & \multicolumn{2}{|c|}{$\begin{array}{l}\text { Postotni udio prema } \\
\text { Percentage per }\end{array}$} & \multirow{2}{*}{$\begin{array}{l}\text { Ukupno } \\
\text { vrijeme } \\
\text { Total time }\end{array}$} & \multicolumn{2}{|c|}{$\begin{array}{l}\text { Postotni udio prema } \\
\text { Percentage per }\end{array}$} \\
\hline & & $\begin{array}{l}\text { ukupnom vremenu } \\
\text { total time }\end{array}$ & $\begin{array}{c}\text { efektivnom vremenu } \\
\text { effective time }\end{array}$ & & $\begin{array}{l}\text { ukupnom vremenu } \\
\text { total time }\end{array}$ & $\begin{array}{c}\text { efektivnom vremenu } \\
\text { effective time }\end{array}$ \\
\hline & $\min$ & \multicolumn{2}{|c|}{$\%$} & $\min$ & \multicolumn{2}{|c|}{$\%$} \\
\hline $\begin{array}{l}\text { 1. Vožnja neopterećenoga skidera } \\
\text { Unloaded skidder travel }\end{array}$ & 408,45 & 13,91 & 18,36 & 205,66 & 9,67 & 16,84 \\
\hline $\begin{array}{l}\text { 2. Rad opterećenoga skidera } \\
\text { Loaded skidder work }\end{array}$ & 700,73 & 23,87 & 31,49 & 337,75 & 15,88 & 27,66 \\
\hline $\begin{array}{l}2.1 \text { Vožnja opterećenoga skidera } \\
\text { Loaded skidder travel }\end{array}$ & 687,83 & 23,43 & 30,91 & 286,44 & 13,47 & 23,45 \\
\hline 2.2 Privitlavanje u vožnji - Travel winching & 12,90 & 0,44 & 0,58 & 51,31 & 2,41 & 4,20 \\
\hline 3. Rad na sječini - Felling site work & 603,47 & 20,55 & 27,12 & 266,39 & 12,53 & 21,81 \\
\hline 3.1 Zauzimanje položaja - Positioning & 37,35 & 1,27 & 1,68 & 14,65 & 0,69 & 1,20 \\
\hline 3.2 Izvlačenje užeta - Line pulling & 142,53 & 4,85 & 6,41 & 51,64 & 2,43 & 4,23 \\
\hline 3.3 Vezanje tovara - Choking & 89,36 & 3,04 & 4,02 & 59,01 & 2,77 & 4,83 \\
\hline 3.4 Privitlavanje - Winching & 138,33 & 4,71 & 6,22 & 131,38 & 6,18 & 10,76 \\
\hline 3.5 Formiranje tovara - Load forming & 179,70 & 6,12 & 8,08 & 3,34 & 0,16 & 0,27 \\
\hline $\begin{array}{l}\text { 3.6 Silaženje i penjanje - Going uphill and } \\
\text { downhill }\end{array}$ & 16,20 & 0,55 & 0,73 & 6,37 & 0,30 & 0,52 \\
\hline $\begin{array}{l}\text { 4. Rad na pomoćnom stovarištu } \\
\text { Landing work }\end{array}$ & 512,43 & 17,45 & 23,03 & 411,48 & 19,35 & 33,69 \\
\hline $\begin{array}{l}\text { 4.1 Vožnja opterećenoga skidera } \\
\text { Loaded skidder travel }\end{array}$ & 70,63 & 2,41 & 3,17 & 111,07 & 5,22 & 9,09 \\
\hline 4.2 Privitlavanje u vožnji - Travel winching & 0,91 & 0,03 & 0,04 & 10,72 & 0,50 & 0,88 \\
\hline $\begin{array}{l}\text { 4.3 Silaženje i penjanje - Going uphill and } \\
\text { downhill }\end{array}$ & 5,70 & 0,19 & 0,26 & 21,79 & 1,02 & 1,78 \\
\hline 4.4 Odvezivanje tovara - Unchoking & 165,04 & 5,62 & 7,42 & 39,26 & 1,84 & 3,21 \\
\hline 4.5 Uređenje složaja - Bunching & 187,77 & 6,39 & 8,44 & 141,99 & 6,68 & 11,63 \\
\hline 4.6 Okretanje skidera - Skidder turning & 42,36 & 1,44 & 1,90 & 27,04 & 1,27 & 2,21 \\
\hline $\begin{array}{l}\text { 4.7 Vožnja neopterećenoga skidera } \\
\text { Unloaded skidder travel }\end{array}$ & 40,02 & 1,36 & 1,80 & 59,61 & 2,80 & 4,88 \\
\hline 5. Efektivno vrijeme - Effective time & 2225,08 & 75,78 & 100,00 & 1221,28 & 57,43 & 100,00 \\
\hline 6. Opće vrijeme - Delay time & 711,14 & 24,22 & & 905,26 & 42,57 & \\
\hline 7. Ukupno vrijeme - Total time & 2936,22 & 100,00 & & 2126,54 & 100,00 & \\
\hline $\begin{array}{l}\text { 8. Ukupno privučeni drvni obujam, } \mathrm{m}^{3} \\
\text { Total skidded timber volume, } \mathrm{m}^{3}\end{array}$ & 198,25 & & & 193,27 & & \\
\hline $\begin{array}{l}\text { 9. Efektivno vrijeme po jedinici, } \mathrm{min} / \mathrm{m}^{3} \\
\text { Effective time per unit, } \mathrm{min} / \mathrm{m}^{3}\end{array}$ & 11,22 & & & 6,32 & & \\
\hline $\begin{array}{l}\text { 10. Ukupno vrijeme po jedinici, } \mathrm{min} / \mathrm{m}^{3} \\
\text { Total time per unit, } \mathrm{min} / \mathrm{m}^{3}\end{array}$ & 14,81 & & & 8,28 & & \\
\hline $\begin{array}{l}\text { 11. Ostvareni dnevni učinak, } \mathrm{m}^{3} / \mathrm{dan} \\
\text { Daily output, } \mathrm{m}^{3} / \text { day }\end{array}$ & 28,31 & & & 38,65 & & \\
\hline
\end{tabular}

Utjecaj vrste sječe preko dopuštene metode privlačenja drva na srednji obujam tovara vidljiv je $u$ istraživanjima proizvodnosti privlačenja drva skiderom Timberjack 240C. Zečić i dr. (2004c) pri istraživanju privlačenja deblovnom metodom navede- noga skidera u dovršnom sijeku mješovite bukove sastojine utvrđuju srednji obujam tovara od $4,24 \mathrm{~m}^{3}$. U prebornoj sječi isti skider postiže u sortimentnoj metodi srednji obujam tovara od $4,63 \mathrm{~m}^{3}$ (Zečić i dr. 2010), a u čistoj sječi euroameričke topole deblov- 
nom metodom postiže srednji obujam tovara od čak $8,63 \mathrm{~m}^{3}$ (Zečić i dr. 2011a).

Struktura dodatnoga vremena prikazana je $\mathrm{u}$ tablici 2. Faktor dodatnoga vremena iznosi 1,22 za radilište $A$ i 1,31 za radilište $B$. Za isti skider $u$ brdskim uvjetima središnje Hrvatske, prema Horvatu i dr. (2007), faktor dodatnoga vremena iznosi 1,34, a u gorskim uvjetima prebornih šuma 1,18. Na osnovi tih podataka zaključuje se da dodatno vrijeme ne ovisi toliko o sastojinskim i eksploatacijskim čimbenicima koliko o organizaciji i nadzoru izvođenja radova pri privlačenju drva.

Tablica 2. Dodatno vrijeme skidera Ecotrac $120 \mathrm{~V}$ Table 2 Allowance time of Ecotrac 120V skidder

\begin{tabular}{|l|c|c|c|c|}
\hline \multirow{2}{*}{$\begin{array}{l}\text { Vrsta vremena ili prekida rada } \\
\text { Type of time or work interruption }\end{array}$} & \multicolumn{2}{|c|}{$\begin{array}{c}\text { Radilište A } \\
\text { Work site } A\end{array}$} & \multicolumn{2}{c|}{$\begin{array}{c}\text { Radilište B } \\
\text { Work site B }\end{array}$} \\
\cline { 2 - 5 } & \multicolumn{2}{|c|}{ Vrijeme - Time } & \multicolumn{2}{c|}{ Vrijeme - Time } \\
\cline { 2 - 5 } & min & $\%$ & min & $\%$ \\
\hline $\begin{array}{l}\text { 1. Pripremno-završno vrijeme - } \\
\text { Preparatory time }\end{array}$ & 143,29 & 29,43 & 95,00 & 25,07 \\
\hline 2. Prekid za jelo - Meal time & 180,00 & 36,97 & 148,11 & 39,09 \\
\hline $\begin{array}{l}\text { 3. Odmor - Resting time } \\
\text { 4. Ostali prekidi i povremeni } \\
\text { radovi } \\
\text { Other interruptions and } \\
\text { occasional work }\end{array}$ & 48,08 & 9,87 & 26,89 & 7,10 \\
\hline $\begin{array}{l}\text { Dodatno vrijeme } \\
\text { Allowance time }\end{array}$ & 486,93 & 100,00 & 378,90 & 100,00 \\
\hline $\begin{array}{l}\text { Efektivno vrijeme } \\
\text { Effective time }\end{array}$ & 2225,08 & 108,90 & 28,74 \\
\hline $\begin{array}{l}\text { Dodatno vrijeme } \\
\text { Allowance time }\end{array}$ & 486,93 & 21,88 & 378,90 & 31,02 \\
\hline $\begin{array}{l}\text { Faktor dodatnoga vremena } \\
\text { Allowance time factor }\end{array}$ & 1,22 & \multicolumn{2}{|c|}{1,31} \\
\hline
\end{tabular}

U tablici 3 prikazani su rezultati provedenoga $t$-testa brzine vožnji, izvlačenja užeta i privitlavanja na obama radilištima. Za sve radne zahvate, osim za vožnju opterećenoga skidera po vlaci i izvlačenje užeta, brzina se značajno razlikuje te je $u$ daljnjim izračunima korištena pojedinačna brzina svakoga radilišta. Za radne zahvate za koje nisu utvrđene statistički značajne razlike $\mathrm{u}$ brzini izračunata je zajednička prosječna brzina, i to: za vožnju opterećenoga skidera po vlaci $2,94 \mathrm{~km} / \mathrm{h}$, a za izvlačenje užeta $2,62 \mathrm{~km} / \mathrm{h}$.

Prilikom istraživanja na radilištu A utvrđena je prosječna udaljenost privlačenja drva po pomoćnom stovarištu u iznosu od $60 \mathrm{~m}$, dok je na radilištu B iznosila $100 \mathrm{~m}$. Za izračun projektiranih, usporedivih učinaka korištena je prosječna vrijednost od 80 $\mathrm{m}$ za oba radilišta.
Utrošci vremena i odnosne udaljenosti izvlačenja užeta i privitlavanja su, kako je već spomenuto, evidentirani na razini pojedinoga bubnja vitla. Međutim, pri statističkoj obradi snimljene su vrijednosti razvrstane na razini skidera/radilišta, kao što je i vidljivo iz prikazane veličine uzorka u tablici 3. Podrobnijom analizom snimljenih podataka utvrđeno je da su se prilikom privitlavanja na radilištu A gotovo u svim turnusima (66 turnusa) koristila oba bubnja vitla, dok se na radilištu B uglavnom koristio samo jedan bubanj. Korištenje drugoga bubnja vitla na radilištu $B$ evidentirano je $u$ samo 15 turnusa (od ukupno 52 turnusa). Zbog toga su izračunate prosječne udaljenosti izvlačenja užeta/ privitlavanja za svaki bubanj vitla posebno, i to tako da je ukupna snimljena udaljenost izvlačenja užeta/privitlavanja, po bubnju, svih turnusa podijeljena ukupnim brojem turnusa. Utvrđeno je da se na radilištu A desni bubanj vitla koristio za privlačenje $\mathrm{s}$ prosječne udaljenosti $45 \mathrm{~m}$, a lijevi bubanj vitla s prosječne udaljenosti $37 \mathrm{~m}$, dok se na radilištu B desni bubanj vitla koristio za privitlavanje $\mathrm{s}$ prosječne udaljenosti $31 \mathrm{~m}$, a lijevi bubanj vitla $\mathrm{s}$ prosječne udaljenosti od samo $8 \mathrm{~m}$. Navedeni rezultati objašnjavaju bitno veći udio utroška vremena za rad na sječini na radilištu A nego na radilištu B i u strukturi snimljenoga vremena (tablica 1) i u strukturi vremena projektiranoga turnusa privlačenja (tablica 5). Rezultati pokazuju bitan utjecaj različite sječne gustoće proredne sječine $\left(34,07 \mathrm{~m}^{3} /\right.$ ha na radilištu A) i dovršne sječine $\left(89,50 \mathrm{~m}^{3} /\right.$ ha na radilištu $B$ ) na utrošak vremena rada na sječini i posljedično na ostvarivi dnevni učinak. Na proizvodnost rada skidera uz sječnu gustoću još veći utjecaj ima prosječni obujam posječenoga stabla $\left(0,63 \mathrm{~m}^{3}\right.$ na radilištu A i 3,51 $\mathrm{m}^{3}$ na radilištu $\left.B\right)$ jer omogućuje formiranje tovara zadovoljavajućega obujma na kratkoj udaljenosti privitlavanja vezivanjem manjega broja komada, često uz korištenje samo jednoga bubnja vitla. Upravo u optimalnom odnosu između veličine tovara i vremena utrošenoga za njegovo oblikovanje pri radu na sječini leži mogućnost postizanja najvećih učinaka u zadanim sastojinskim i eksploatacijskim uvjetima.

Slična se mišljenja mogu donijeti proučavajući objavljena istraživanja. Tako Zečić i dr. (2004a) pri proučavanju adaptiranih poljoprivrednih traktora pišu da traktor opremljen jednobubanjskim vitlom ostvaruje nešto veći srednji obujam tovara $u$ dovršnom sijeku nego u pripremnom uz manji udio rada na sječini u ukupnom efektivnom vremenu. Za traktor s dvobubanjskim vitlom taj se zaključak na temelju rezultata navedenoga istraživanja ne može 
donijeti jer neznatno povećanje obujma tovara u dovršnom sijeku prati i povećanje udjela rada na sječini u ukupnom efektivnom vremenu. U istraživanju učinkovitosti privlačenja drva deblovnom metodom skiderom Timberjack 240C Krpan i Zečić (2001) u dovršnom sijeku (sječna gustoća $95,93 \mathrm{~m}^{3} /$ ha; prosječni obujam posječenoga stabla $4,16 \mathrm{~m}^{3}$ ) i u pripremnom sijeku (sječna gustoća $54,04 \mathrm{~m}^{3} /$ ha; prosječni obujam posječenoga stabla $1,94 \mathrm{~m}^{3}$ ) utvrđuju srednji obujam tovara od $4,24 \mathrm{~m}^{3} \mathrm{u}$ dovršnom i $6,31 \mathrm{~m}^{3} \mathrm{u}$ pripremnom sijeku. Iako se rezultati navedenoga i ovdje prikazanoga istraživanja mogu na prvi pogled činiti oprečnima, struktura vremena turnusa kazuje da je za rad na sječini pripremnoga sijeka utrošeno trostruko više vremena $\mathrm{u}$ apsolutnom iznosu i gotovo dvostruko više vremena $u$ relativnom iznosu prema efektivnomu vremenu. Sve je to rezultiralo $27 \%$ manjim učinkom u pripremnom sijeku. Glavni razlog tih rezultata leži u težnji radnika da zbog mnogo veće udaljenosti privlačenja $u$ pripremnom sijeku $(800 \mathrm{~m})$ nego u dovršnom sijeku $(300 \mathrm{~m})$ formira što veći tovar (Krpan i Zečić 2001). Sabo i Poršinsky (2005) za isti skider na privlačenju drva u dvjema prebornim sječinama (sječna gustoća 54,2 $\mathrm{m}^{3} /$ ha i $70,0 \mathrm{~m}^{3} /$ ha; prosječni obujam posječenoga stabla $3,2 \mathrm{~m}^{3}$ i 3,9 $\mathrm{m}^{3}$ ) utvrđuju da ne postoji značajna razlika u obujmu tovara te da je udio rada u sječini u strukturi ukupno snimljenoga vremena približno isto. Prema rezultatima israživanja skidera Ecotrac
120V (Zečić 2006) u pripremnom sijeku tvrdih listača (sječna gustoća $128,11 \mathrm{~m}^{3} /$ ha; prosječni obujam posječenoga stabla $0,52 \mathrm{~m}^{3}$; prosječna udaljenost privitlavanja $10,5 \mathrm{~m}$ ) i prebornoj sječini (sječna gustoća $46,05 \mathrm{~m}^{3} /$ ha; prosječni obujam posječenoga stabla $1,59 \mathrm{~m}^{3}$; prosječna udaljenost privitlavanja $21,8 \mathrm{~m}$ ) ostvaren je srednji obujam tovara od 2,78 $\mathrm{m}^{3}$, odnosno $5,34 \mathrm{~m}^{3}$. Međutim, ostvareni su trostruko veći apsolutni utrošci vremena rada na prebornoj sječini, što za posljedicu ima nešto veći projektirani dnevni učinak u pripremnom sijeku. Pri interpretaciji navedenih rezultata treba imati na umu različitu gustoću drva listača i četinjača te različite sastojinske uvjete koji vladaju u brdskom području središnje Hrvatske za razliku od onih u gorskom području prebornih šuma.

T-testom utrošaka vremena radnih zahvata na vlaci i sječini te rada na pomoćnom stovarištu (tablica 4) utvrđeno je da značajna razlika u utrošku navedenoga vremena na radilištu A i na radilištu B postoji za sve radne zahvate na obama radilištima, osim za vezanje tovara i silaženje i penjanje (na vlaci i sječini) te za uhrpavanje (na pomoćnom stovarištu). U skladu s tim za radne zahvate za koje je utvrđena značajna razlika (u tablicama 3 i 4 podebljani brojevi) u daljnjim su izračunima upotrijebljene pojedinačne vrijednosti. Za ostale radne zahvate izračunate su zajedničke prosječne vrijednosti, i to

Tablica 3. Rezultati t-testa brzine vožnji, izvlačenja užeta i privitlavanja skidera Ecotrac $120 \mathrm{~V}$ na radilištima A i B

Table 3 T-test results of Ecotrac $120 \mathrm{~V}$ skidder travel speeds, line pulling speeds and winching speeds at felling sites $A$ and $B$

\begin{tabular}{|c|c|c|c|c|c|c|c|c|c|c|c|}
\hline \multirow{2}{*}{$\begin{array}{c}\text { Radna sastavnica } \\
\text { Work element }\end{array}$} & \multicolumn{2}{|c|}{ Sredina - Mean } & \multirow{2}{*}{ t-value } & \multirow{2}{*}{$d f$} & \multirow{2}{*}{$p$} & \multicolumn{2}{|c|}{ Uzorak - Valid N } & \multicolumn{2}{|c|}{ Std. dev. } & \multirow{2}{*}{$\begin{array}{l}\text { F-ratio } \\
\text { Variances }\end{array}$} & \multirow{2}{*}{$\begin{array}{c}P \\
\text { Variances }\end{array}$} \\
\hline & A & B & & & & $A$ & B & A & B & & \\
\hline $\begin{array}{l}\text { Vožnja neopterećen } \\
\text { po pomoćnom stovarištu, } \mathrm{km} / \mathrm{h} \\
\text { Travel unloaded on landing site, } \mathrm{km} / \mathrm{h}\end{array}$ & 6,15 & 5,33 & 2,842604 & 110 & 0,005335 & 64 & 48 & 1,45 & 1,63 & 1,273325 & 0,368236 \\
\hline $\begin{array}{l}\text { Vožnja neopterećen po vlaki, } \mathrm{km} / \mathrm{h} \\
\text { Travel unloaded on skid trail, } \mathrm{km} / \mathrm{h}\end{array}$ & 5,08 & 4,30 & 3,792967 & 115 & 0,000239 & 65 & 52 & 0,40 & 1,60 & 16,27474 & 0,000000 \\
\hline $\begin{array}{l}\text { Vožnja opterećen po vlaki, } \mathrm{km} / \mathrm{h} \\
\text { Travel loaded on skid trail, } \mathrm{km} / \mathrm{h}\end{array}$ & 3,02 & 2,84 & 1,387568 & 115 & 0,167951 & 65 & 52 & 0,33 & 1,03 & 10,00406 & 0,000000 \\
\hline $\begin{array}{l}\text { Vožnja opterećen } \\
\text { po pomoćnom stovarištu, } \mathrm{km} / \mathrm{h} \\
\text { Travel loaded on landing site, } \mathrm{km} / \mathrm{h}\end{array}$ & 3,54 & 3,11 & 2,482665 & 113 & 0,014510 & 65 & 50 & 0,86 & 0,98 & 1,305321 & 0,315174 \\
\hline $\begin{array}{l}\text { Izvlačenje užeta, } \mathrm{km} / \mathrm{h} \\
\text { Line pulling, } \mathrm{km} / \mathrm{h}\end{array}$ & 2,52 & 2,82 & $-1,78947$ & 190 & 0,075132 & 130 & 62 & 1,03 & 1,22 & 1,396054 & 0,116940 \\
\hline $\begin{array}{l}\text { Privitlavanje, } \mathrm{km} / \mathrm{h} \\
\text { Winching, } \mathrm{km} / \mathrm{h}\end{array}$ & 2,89 & 1,57 & 7,248976 & 191 & 0,000000 & 130 & 63 & 1,30 & 0,90 & 2,093854 & 0,001477 \\
\hline
\end{tabular}


za vezanje tovara (1,26 min), za silaženje i penjanje (0,19 $\mathrm{min})$ te za uhrpavanje (2,80 $\mathrm{min})$.

Rezultati prikazani u tablici 5 pokazuju da se za vožnje skidera na usporedivim udaljenostima utrošilo više vremena na radilištu B nego na radilištu A, dok je za rad na sječini te za rad na pomoćnom stovarištu utrošeno mnogo više vremena na radilištu A nego na radilištu B. Razlike $u$ utrošku vremena za vožnju opterećenoga skidera po vlaci za iste odnosne udaljenosti i istu prosječnu brzinu vožnje leže u većem utrošku vremena za privitlavanje tijekom vožnje na radilištu $B$.

Utrošak je efektivnoga vremena za sve odnosne srednje udaljenosti privlačenja po vlaci veći na radilištu A nego na radilištu B. Nakon pribrajanja dodatnoga vremena, koje je u relativnom iznosu za
$10 \%$ veće kod radilišta $B$, vidljiv je manji utrošak ukupnoga vremena i veći broj mogućih ostvarivih turnusa na radilištu A za odnosne srednje udaljenosti privlačenja po vlaci od $700 \mathrm{~m}$ nadalje.

Norma vremena, zbog većega srednjega tovara na radilištu $B$, zadržava trend utroška efektivnoga vremena, što na kraju rezultira većim dnevnim utrošcima (slika 2) i manjim jediničnim troškovima (slika 3) na radilištu B nego na radilištu A za sve odnosne srednje udaljenosti privlačenja po vlaci.

Dnevni je učinak na radilištu A manji, od $30 \%$ na srednjoj udaljenosti privlačenja po vlaci $100 \mathrm{~m}$ do $15 \%$ na $1000 \mathrm{~m}$, od dnevnoga učinka na istim udaljenostima na radilištu B. Jedinični je trošak na radilištu A za iste, navedene udaljenosti od $42 \%$ do $18 \%$ veći nego na radilištu $B$.

Tablica 4. Rezultati t-testa utrošaka vremena rada na sječini i vlaci te na pomoćnom stovarištu skidera Ecotrac $120 \mathrm{~V}$ za radilišta A i B Table 4 T-test results of Ecotrac 120V skidder time consumption for work at the felling site and skid trail and at the landing for felling sites $A$ and $B$

\begin{tabular}{|c|c|c|c|c|c|c|c|c|c|c|c|c|}
\hline & \multirow{2}{*}{$\begin{array}{l}\text { Radna sastavnica, min } \\
\text { Work element, min }\end{array}$} & \multicolumn{2}{|c|}{ Sredina - Mean } & \multirow{2}{*}{$t$-value } & \multirow{2}{*}{$d f$} & \multirow{2}{*}{$p$} & \multicolumn{2}{|c|}{ Uzorak - Valid N } & \multicolumn{2}{|c|}{ Std. dev. } & \multirow{2}{*}{$\begin{array}{c}\text { F-ratio } \\
\text { Variances }\end{array}$} & \multirow{2}{*}{$\begin{array}{c}P \\
\text { Variances }\end{array}$} \\
\hline & & A & $B$ & & & & A & $B$ & $A$ & $B$ & & \\
\hline \multirow{7}{*}{ 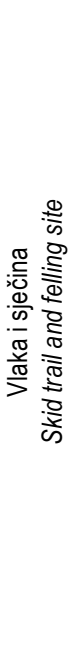 } & $\begin{array}{l}\text { Privitlavanje u vožnji } \\
\text { Travel winching }\end{array}$ & 0,20 & 0,99 & $-4,39246$ & 116 & 0,000025 & 66 & 52 & 0,37 & 1,41 & 14,78143 & 0,000000 \\
\hline & $\begin{array}{l}\text { Zauzimanje položaja } \\
\text { Positioning }\end{array}$ & 0,57 & 0,28 & 4,916468 & 116 & 0,000003 & 66 & 52 & 0,33 & 0,28 & 1,381396 & 0,232086 \\
\hline & $\begin{array}{l}\text { Vezanje tovara } \\
\text { Choking }\end{array}$ & 1,35 & 1,13 & 1,598227 & 116 & 0,112713 & 66 & 52 & 0,73 & 0,75 & 1,069476 & 0,791941 \\
\hline & $\begin{array}{l}\text { Vezanje tovara DB } \\
\text { Choking } R D\end{array}$ & 0,68 & 1,00 & $-2,96506$ & 116 & 0,003674 & 66 & 52 & 0,41 & 0,75 & 3,296160 & 0,000008 \\
\hline & $\begin{array}{l}\text { Vezanje tovara LB } \\
\text { Choking LD }\end{array}$ & 0,67 & 0,13 & 6,602162 & 116 & 0,000000 & 66 & 52 & 0,54 & 0,28 & 3,796645 & 0,000002 \\
\hline & $\begin{array}{l}\text { Formiranje tovara } \\
\text { Load forming }\end{array}$ & 2,72 & 0,06 & 12,10681 & 116 & 0,000000 & 66 & 52 & 1,57 & 0,17 & 81,47627 & 0,00 \\
\hline & $\begin{array}{l}\text { Silaženje i penjanje } \\
\text { Going uphill and downhill }\end{array}$ & 0,25 & 0,12 & 1,604273 & 116 & 0,111373 & 66 & 52 & 0,27 & 0,55 & 4,218465 & 0,000000 \\
\hline \multirow{5}{*}{ 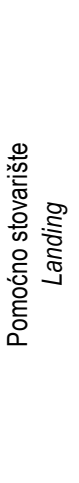 } & $\begin{array}{l}\text { Privitlavanje u vožnji } \\
\text { Travel winching }\end{array}$ & 0,01 & 0,21 & $-2,94848$ & 116 & 0,003863 & 66 & 52 & 0,08 & 0,52 & 41,02032 & 0,00 \\
\hline & $\begin{array}{l}\text { Odvezivanje tovara } \\
\text { Unchoking }\end{array}$ & 2,50 & 0,76 & 10,52391 & 116 & 0,000000 & 66 & 52 & 1,13 & 0,45 & 6,386578 & 0,000000 \\
\hline & $\begin{array}{l}\text { Uhrpavanje } \\
\text { Bunching }\end{array}$ & 2,85 & 2,73 & 0,262790 & 116 & 0,793178 & 66 & 52 & 2,39 & 2,29 & 1,088797 & 0,757377 \\
\hline & $\begin{array}{l}\text { Okretanje skidera } \\
\text { Skidder turning }\end{array}$ & 0,64 & 0,52 & 2,152154 & 116 & 0,033457 & 66 & 52 & 0,33 & 0,26 & 1,601231 & 0,082400 \\
\hline & $\begin{array}{l}\text { Silaženje i penjanje } \\
\text { Going uphill and } \\
\text { downhill }\end{array}$ & 0,09 & 0,42 & $-10,5143$ & 116 & 0,000000 & 66 & 52 & 0,20 & 0,13 & 2,186843 & 0,004303 \\
\hline
\end{tabular}


Tablica 5. Ovisnost utrošaka vremena, norme vremena i broja turnusa dnevno o srednjoj udaljenosti privlačenja za skider Ecotrac $120 \mathrm{~V}$ Table 5 Time consumption, standard time and number of cycles per day vs. average skidding distance for Ecotrac 120V skidder

\begin{tabular}{|c|c|c|c|c|c|c|c|c|c|c|c|c|}
\hline \multirow{2}{*}{ 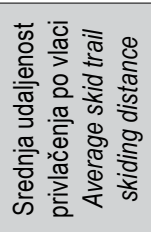 } & \multicolumn{2}{|c|}{$\begin{array}{l}\text { Vožnja po vlaci } \\
\text { Skid trail travel }\end{array}$} & \multicolumn{2}{|c|}{$\begin{array}{c}\text { Vožnja po stovarištu } \\
\text { Landing travel }\end{array}$} & \multirow{2}{*}{ 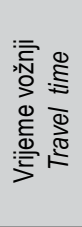 } & \multirow{2}{*}{ 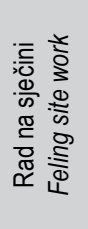 } & \multirow{2}{*}{ 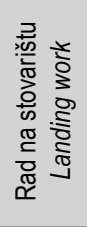 } & \multirow{2}{*}{ 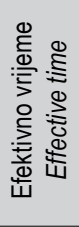 } & \multirow{2}{*}{ 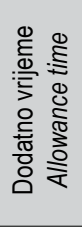 } & \multirow{2}{*}{ 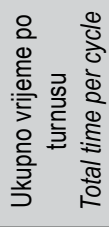 } & \multirow{2}{*}{ 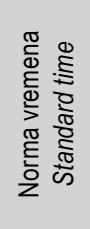 } & \multirow{2}{*}{ 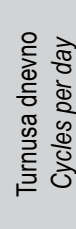 } \\
\hline & 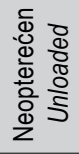 & 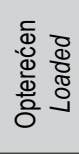 & 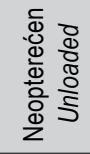 & 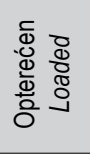 & & & & & & & & \\
\hline $\mathrm{m}$ & \multicolumn{10}{|c|}{$\min$} & $\mathrm{min} / \mathrm{m}^{3}$ & $\mathrm{~N}$ \\
\hline \multicolumn{13}{|c|}{ Radilište A - Worksite A } \\
\hline 100 & 1,18 & 2,24 & 0,78 & 1,37 & 5,57 & 8,32 & 6,03 & 19,92 & 4,18 & 24,10 & 7,90 & 19,9 \\
\hline 200 & 2,36 & 4,28 & 0,78 & 1,37 & 8,79 & 8,32 & 6,03 & 23,14 & 4,86 & 28,00 & 9,18 & 17,1 \\
\hline 300 & 3,54 & 6,32 & 0,78 & 1,37 & 12,01 & 8,32 & 6,03 & 26,36 & 5,54 & 31,90 & 10,46 & 15,0 \\
\hline 400 & 4,72 & 8,36 & 0,78 & 1,37 & 15,23 & 8,32 & 6,03 & 29,58 & 6,21 & 35,80 & 11,74 & 13,4 \\
\hline 500 & 5,91 & 10,40 & 0,78 & 1,37 & 18,46 & 8,32 & 6,03 & 32,81 & 6,89 & 39,70 & 13,01 & 12,1 \\
\hline 600 & 7,09 & 12,44 & 0,78 & 1,37 & 21,68 & 8,32 & 6,03 & 36,03 & 7,57 & 43,59 & 14,29 & 11,0 \\
\hline 700 & 8,27 & 14,49 & 0,78 & 1,37 & 24,90 & 8,32 & 6,03 & 39,25 & 8,24 & 47,49 & 15,57 & 10,1 \\
\hline 800 & 9,45 & 16,53 & 0,78 & 1,37 & 28,12 & 8,32 & 6,03 & 42,47 & 8,92 & 51,39 & 16,85 & 9,3 \\
\hline 900 & 10,63 & 18,57 & 0,78 & 1,37 & 31,34 & 8,32 & 6,03 & 45,69 & 9,60 & 55,29 & 18,13 & 8,7 \\
\hline 1000 & 11,81 & 20,61 & 0,78 & 1,37 & 34,57 & 8,32 & 6,03 & 48,92 & 10,27 & 59,19 & 19,41 & 8,1 \\
\hline \multicolumn{13}{|c|}{ Radilište B - Worksite $B$} \\
\hline 100 & 1,40 & 3,03 & 0,90 & 1,75 & 7,08 & 4,17 & 4,50 & 15,75 & 4,88 & 20,64 & 5,55 & 23,3 \\
\hline 200 & 2,79 & 5,07 & 0,90 & 1,75 & 10,52 & 4,17 & 4,50 & 19,19 & 5,95 & 25,14 & 6,76 & 19,1 \\
\hline 300 & 4,19 & 7,11 & 0,90 & 1,75 & 13,95 & 4,17 & 4,50 & 22,63 & 7,01 & 29,64 & 7,97 & 16,2 \\
\hline 400 & 5,58 & 9,15 & 0,90 & 1,75 & 17,39 & 4,17 & 4,50 & 26,06 & 8,08 & 34,14 & 9,19 & 14,1 \\
\hline 500 & 6,98 & 11,19 & 0,90 & 1,75 & 20,82 & 4,17 & 4,50 & 29,50 & 9,14 & 38,64 & 10,40 & 12,4 \\
\hline 600 & 8,37 & 13,23 & 0,90 & 1,75 & 24,26 & 4,17 & 4,50 & 32,93 & 10,21 & 43,14 & 11,61 & 11,1 \\
\hline 700 & 9,77 & 15,28 & 0,90 & 1,75 & 27,70 & 4,17 & 4,50 & 36,37 & 11,27 & 47,65 & 12,82 & 10,1 \\
\hline 800 & 11,16 & 17,32 & 0,90 & 1,75 & 31,13 & 4,17 & 4,50 & 39,81 & 12,34 & 52,15 & 14,03 & 9,2 \\
\hline 900 & 12,56 & 19,36 & 0,90 & 1,75 & 34,57 & 4,17 & 4,50 & 43,24 & 13,41 & 56,65 & 15,24 & 8,5 \\
\hline 1000 & 13,95 & 21,40 & 0,90 & 1,75 & 38,01 & 4,17 & 4,50 & 46,68 & 14,47 & 61,15 & 16,45 & 7,8 \\
\hline
\end{tabular}

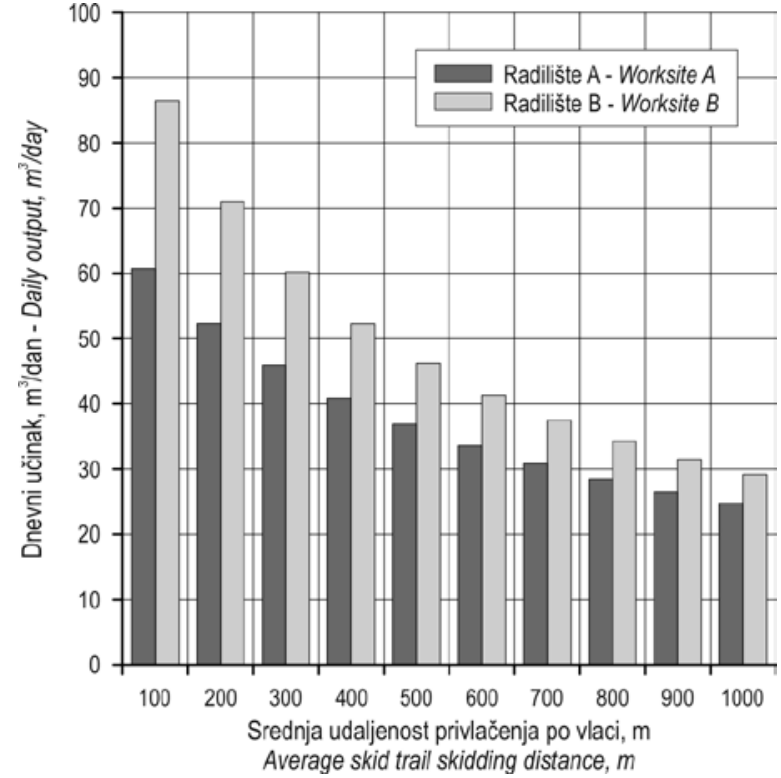

Slika 2. Ovisnost dnevnoga učinka o srednjoj udaljenosti privlačenja za skider Ecotrac $120 \mathrm{~V}$

Fig. 2 Daily output vs. average skidding distance for Ecotrac 120V skidder

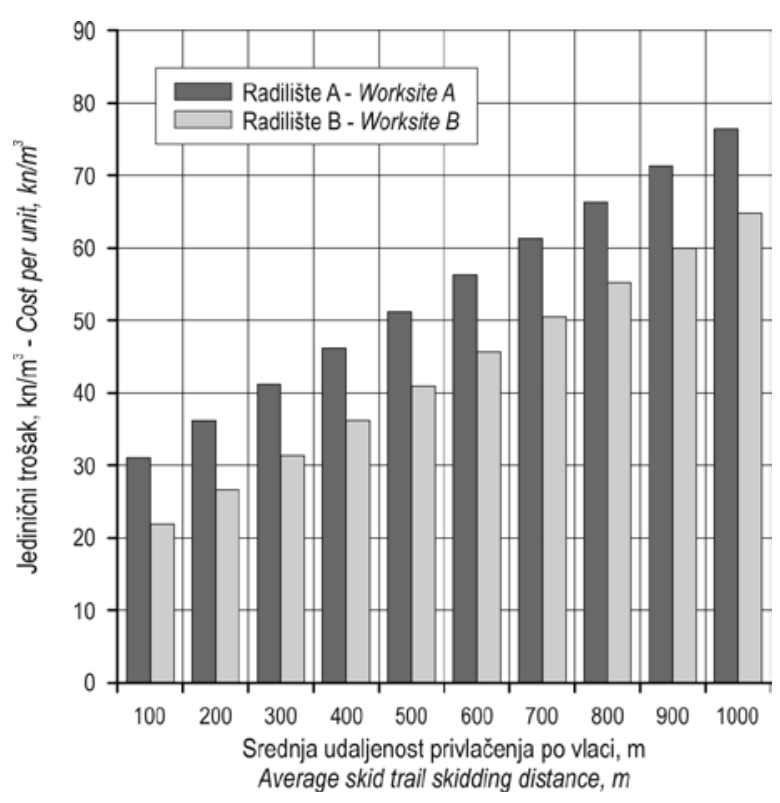

Slika 3. Ovisnost jediničnoga troška o srednjoj udaljenosti privlačenja za skider Ecotrac $120 \mathrm{~V}$

Fig. 3 Cost per unit vs. average skidding distance for Ecotrac $120 \mathrm{~V}$ skidder 


\section{Zaključci - Conclusions}

U radu je utvrđeno da skider Ecotrac $120 \mathrm{~V}$ prosječno postiže $21 \%$ veći projektirani dnevni učinak u dovršnom sijeku (B) nego u prorednom sijeku (A) uz prosječno $26 \%$ niže jedinične troškove. Podrobnom analizom utrošaka vremena pojedinih radnih zahvata dolazi se do zaključaka da na razliku u proizvodnosti i troškovima bitan utjecaj imaju sječna gustoća sastojine i prosječan obujam posječenoga stabla. Različita sječna gustoća utječe na različit utrošak vremena rada na sječini i posljedično na ostvarivi dnevni učinak.

Na proizvodnost rada skidera uz sječnu gustoću još veći utjecaj ima prosječni obujam posječenoga stabla jer omogućuje formiranje tovara zadovoljavajućega obujma na kratkoj udaljenosti privitlavanja vezivanjem manjega broja komada, često uz upotrebu samo jednoga bubnja vitla.

Stoga možemo zaključiti da mogućnost postizanja najvećih učinaka u zadanim sastojinskim i eksploatacijskim uvjetima leži u optimalnom odnosu između veličine tovara i vremena utrošenoga pri radu na sječini, koje je nužno za njegovo oblikovanje.

\section{Literatura - References}

Anon., 2008: Interne prodajne cijene usluga radnika, strojeva i vozila »Hrvatskih šuma $u$ u 2008. godini. »Hrvatske šume« d.o.o., Zagreb, 1-8.

Horvat, D., Ž. Zečić, M. Šušnjar, 2007: Morphological characteristics and productivity of skidder Ecotrac 120V. Croatian Journal of Forest Engineering 26(1): 13-27.

Krč, J., B. Košir, 2008: Predicting wood skidding direction on steep terrain by DEM and forest road network extension. Croatian Journal of Forest Engineering 28(1): 11-25.

Krpan, A.P.B., Ž. Zečić, 2001: Učinkovitost i troškovi traktora Timberjack $240 \mathrm{C}$ pri privlačenju drva u brdskim oplodnim sječama. U: Znanost u potrajnom gospodarenju hrvatskim šumama, S. Matić, A.P.B. Krpan, J. Gračan (ur.), Šumarski fakultet Zagreb - Šumarski institut Jastrebarsko, 477-490.

Marenče, J., B. Košir, 2008: Technical parameters dynamics of Woody 110 cable skidder within the range of stopping due to overload in uphill wood skidding. Zbornik gozdarstva in lesarstva 85: 39-48.
Sabo, A., T. Poršinsky, 2005: Skidding of fir roundwood by Timberjack 240C from selective forests of Gorski Kotar. Croatian Journal of Forest Engineering 26(1): 13-27.

Šušnjar, M., A. Bosner, T. Poršinsky, 2010: Vučne značajke skidera pri privlačenju drva niz nagib. Nova mehanizacija šumarstva 31(1): 3-14.

Zečić, Ž., 1998: Skupni rad pri proredama u sastojinama požeškoga gorja s posebnim osvrtom na privlačenje drva traktorima. Magistarski rad, Šumarski fakultet Sveučilišta u Zagrebu, 1-161.

Zečić, Ž., 1999: Teamwork in thinning stands of the Požega mountains with special reference to tractor sikdding. Glasnik za šumske pokuse 36: 13-101.

Zečić, Ž., 2006: Usporedba djelotvornosti traktora Ecotrac $120 \mathrm{~V}$ pri privlačenju drva u brdskim i gorskim uvjetima. Glasnik za šumske pokuse, posebno izdanje 5: 557-572.

Zečić, Ž., A.P.B. Krpan, T. Poršinsky, M. Šušnjar, 2004a: Djelotvornost traktora Steyr 8090 i 9078 u oplodnim sječama sastojina požeškog gorja. Šumarski list 128(5-6): 245-254.

Zečić, Ž., T. Poršinsky, M. Šušnjar, 2004b: Neki rezultati eksploatacije brdskih sastojina skupnim radom uz osvrt na izbor metode studija vremena. Šumarski list 128(7-8): 381-389.

Zečić, Ž., A.P.B. Krpan, B. Stankić, 2004c: Privlačenje oblovine traktorom Timberjack $240 \mathrm{C}$ iz oplodne sječe u uvjetima Šumarije Velika Pisanica. Šumarski list 128(11-12): 671-678.

Zečić, Ž., D. Vusić, M. Prka, S. Klepac, 2010: Utjecaj nagiba traktorskog puta na proizvodnost traktora Timberjack $240 \mathrm{C}$ pri privlačenju drvnih sortimenata u prebornim šumama. Šumarski list 134(3-4): 103-114.

Zečić, Ž., D. Vusić, H. Nevečerel, M. Mikulin, 2011a: Utjecaj obujma tovara na proizvodnost traktora Timberjack 240C pri privlačenju debala euroameričke topole u nizinskim šumama. Croatian Journal of Forest Engineering 32(1): 357-368.

Zečić, Ž., D. Vusić, D. Milković, Z. Marko, 2011b: Skidder with single-drum or double-drum winch in mountainous areas - A case study from selective forests of Croatia. U: $44^{\text {th }}$ International Symposium on Forestry Mechanisation (FORMEC) - Pushing the Boundaries with Research and Innovation in Forest Engineering, K. Stampfer (ur.), BOKU, Graz/Beč. 


\section{Abstract}

\section{Productivity of Tractor Ecotrac 120V Timber Skidding in Hilly Area of Central Croatia}

This paper presents the research results of skidder Ecotrac $120 \mathrm{~V}$ productivity in thinning and final felling half-length wood skidding. Terrain research was conducted using time and motion study at two worksites. Worksite A is a mixed stand of beech $(48.74 \%)$, sessile oak $(4.47 \%)$, hornbeam (21.06\%) and linden (15.65\%), aged 57 years, in which thinning was done. Harvesting density was $34.07 \mathrm{~m}^{3} / \mathrm{ha}$, and mean cutting tree was $0.63 \mathrm{~m}^{3}$. At the worksite B, in the beech (92.03\%) stand, aged 111 years, final felling was conducted. Harvesting density was $89.50 \mathrm{~m}^{3} / \mathrm{ha}$, and mean cutting tree was $3.51 \mathrm{~m}^{3}$. Based on the data collected, the structure of the total time consumption and average daily output was calculated (Table 1). The analysis of recorded delays provided allowance time (Table 2). Differences between load volumes, travel speeds, line pulling and winching speeds and time consumption of individual felling site and landing work elements were investigated by a t-test (Table 3 and Table 4). For those work elements that showed significant differences between worksites, individual mean values were used for further calculations, while for the others, new common mean values were calculated. Travel time consumption was calculated based on the average speed and pertaining skidding distance. A significant difference $(t=-3.571562 ; p=$ 0.000519) was found between load volumes of thinning $\left(3.050 \mathrm{~m}^{3}\right)$ and final felling site $\left(3.717 \mathrm{~m}^{3}\right)$. Differences in time consumption (Table 4 and Table 5) are the most obvious in the group of felling site work elements, and they are a consequence of different line pulling/winching distances needed for forming the achieved load volumes. The projected daily output (Fig. 2) of final felling skidding is in average $21 \%$ higher than in the thinning skidding with an average $26 \%$ lower costs per unit (Fig. 3). Detail analysis of each work element time consumption showed that harvesting density and mean cutting tree volume have an important impact on difference in productivity and costs. Different harvesting densities affect the felling site work time consumption, thus also affecting the achievable productivity. Besides the above mentioned harvesting density, mean cutting tree volume has an even greater influence on skidding productivity because it enables the formation of preferred load volume at short winching distances by choking fewer half-stems, often with the use of just one winch drum. Therefore, it can be concluded that the possibility of achieving greatest outputs, in given stand and harvesting conditions, lies in the optimal relation between the load size and the felling site work time consumption needed for its forming.

Keywords: productivity, costs, harvesting density, mean cutting tree, thinning, final felling

Adresa autorâ - Authors' addresses:

Prof. dr. sc. Željko Zečić* e-pošta: zecic@sumfak.hr Doc. dr. sc. Dinko Vusić e-pošta: vusic@sumfak.hr Doc. dr. sc. Ivica Papa e-pošta: papa@sumfak.hr Sveučilište u Zagrebu Šumarski fakultet Svetošimunska cesta 25 10000 Zagreb HRVATSKA

Primljeno (Received): 16. 5. 2019.

Prihvaćeno (Accepted): 18. 7. 2019.

\footnotetext{
* Glavni autor-Corresponding author
}

Zlatko Benković, dipl. ing. šum. e-pošta: zlatko.benkovic@mps.hr Ministarstvo poljoprivrede Planinska 2a 10000 Zagreb HRVATSKA

Doc. dr. sc. Jurij Marenče e-pošta: jurij.marence@bf.uni-lj.si Biotehniška fakulteta Univerza v Ljubljani Večna pot 83 1000 Ljubljana SLOVENIJA 